\title{
Wenyonia gracilis sp. n. (Cestoda: Caryophyllidea) from Synodontis zambezensis (Siluriformes: Mochokidae): the first native caryophyllidean tapeworm from southern Africa
}

\author{
Bjoern C. Schaeffner ${ }^{1}$, Divan van Rooyen ${ }^{1}$, Ruan Gerber ${ }^{1}$, Tomáš Scholz ${ }^{2}$ and Nico J. Smit ${ }^{1}$ \\ ${ }^{1}$ Water Research Group, Unit for Environmental Sciences and Management, North-West University, Potchefstroom, South Africa; \\ ${ }^{2}$ Institute of Parasitology, Biology Centre of the Academy of Sciences of the Czech Republic, České Budějovice, Czech Republic
}

\begin{abstract}
Parasitological examination of freshwater fishes of the Phongolo River in north-eastern KwaZulu-Natal, South Africa resulted in the discovery and morphological and molecular characterisation of a new species of Wenyonia Woodland, 1923 (Cestoda: Caryophyllidea). The new species from the plain squeaker, Synodontis zambezensis Peters (Siluriformes: Mochokidae), is morphologically most similar to Wenyonia acuminata Woodland, 1923, a species reported from three species of Synodontis in north-eastern, western and central Africa (Sudan, Nigeria, Democratic Republic of the Congo). Both these species are markedly different from congeners by having a nematoform body and a digitiform scolex. Wenyonia gracilis sp. $\mathrm{n}$. differs from W. acuminata in its general body size, length and width of main body regions (testicular and uterine regions), a posterior extension of the testes into the uterine region, numerous postovarian vitelline follicles filling the entire medulla, eggs $c .1 / 3$ larger in size, and a scolex with an apical introvert but devoid of longitudinal furrows and a well-defined base. Wenyonia gracilis is the seventh species in the genus and the first autochthonous caryophyllidean ever reported and described from southern Africa (south of the Zambezi River).
\end{abstract}

Keywords: Tapeworms, fish parasites, new species, molecular characterisation, taxonomy, biodiversity, biogeography, South Africa

Freshwater fishes in Africa have relatively depauperate communities of intestinal helminths, but most of their endoparasites, including cestodes, are endemic to the continent (Scholz et al. 2018). Cestodes are represented by adults of caryophyllideans, bothriocephalideans and onchoproteocephalideans (Scholz and Kuchta 2018). Members of the Caryophyllidea currently include 17 species of seven genera, five of which are autochthonous. With the exception of Atractolytocestus huronensis Anthony, 1958, an invasive parasite which has been introduced to South Africa with the common carp, Cyprinus carpio Linnaeus (Scholz et al. 2015), caryophyllidean tapeworms have not been reported from southern Africa, and especially south of the Zambezi River (Khalil and Polling 1997, Scholz and Kuchta 2018).

Wenyonia Woodland, 1923 represents a monophyletic lineage of caryophyllidean tapeworms infecting exclusively mochokid catfishes of the genus Synodontis Cuvier (Schaeffner et al. 2011). The distribution of members of the genus has been restricted to the Nile River system (Egypt, Sudan) and Sub-Saharan Africa in basins of the rivers Congo (Democratic Republic of the Congo), Gambia (Senegal), Omo (Kenya), Epe and Niger (Nigeria), and Teye and Waanje (Sierra Leone) (Ukoli 1972, Schaeffner et al. 2011, Scholz and Kuchta 2018). They are unique among all caryophyllid- eans in possessing a body with genital pores in the anterior half of the body and a tail-like posterior region (Scholz and Kuchta 2018). These unique characteristics differentiate species of Wenyonia from those of the six remaining caryophyllidean genera present in African freshwater fishes.

Since the erection of the genus by Woodland (1923), seven species have been described (Woodland 1923, 1937, Ukoli 1972). In a recent revision of the genus by Schaeffner et al. (2011), two species have been synonymised and the genus currently includes six accepted taxa, namely Wenyonia virilis Woodland, 1923 (type species), W. acuminata Woodland, 1923, W. longicauda Woodland, 1937, W. minuta Woodland, 1923, W. synodontis Ukoli, 1972, and W. youdeoweii Ukoli, 1972. Wenyonia is considered the species richest genus of caryophyllidean tapeworms in African freshwater systems (Carvalho Schaeffner 2018).

As part of a larger research project focused on the diversity of aquatic parasites in South Africa, a new species of Wenyonia was found in the plain squeaker, Synodontis zambezensis Peters, from the Phongolo River in north-eastern KwaZulu-Natal. This new species represents the first record of a species of Wenyonia and the first native caryophyllidean south of the Zambezi River and southern African freshwater systems. 
Table 1. Nucleotide genetic divergence among species of Wenyonia based on a 538 bp alignment of the partial 28S rRNA gene region. Values below the diagonal are expressed in number of nucleotide differences while values above the diagonal represent the percentage (p-distance).

\begin{tabular}{|c|c|c|c|c|c|c|c|c|c|c|c|c|}
\hline No. & Species & GenBank ID & 1 & 2 & 3 & 4 & 5 & 6 & 7 & 8 & 9 & 10 \\
\hline 1 & W. acuminata & HQ848519 & - & $0 \%$ & $5 \%$ & $4 \%$ & $4 \%$ & $4 \%$ & $4 \%$ & $4 \%$ & $4 \%$ & $5 \%$ \\
\hline 2 & W. acuminata & HQ848489 & 1 & - & $5 \%$ & $4 \%$ & $4 \%$ & $4 \%$ & $4 \%$ & $4 \%$ & $5 \%$ & $5 \%$ \\
\hline 3 & W. gracilis sp. $n$. & MT945943 & 23 & 24 & - & $4 \%$ & $4 \%$ & $4 \%$ & $4 \%$ & $4 \%$ & $4 \%$ & $4 \%$ \\
\hline 4 & W. minuta & HQ848518 & 21 & 22 & 20 & - & $0 \%$ & $0 \%$ & $3 \%$ & $3 \%$ & $3 \%$ & $2 \%$ \\
\hline 5 & W. minuta & HQ848507 & 21 & 22 & 20 & 0 & - & $0 \%$ & $3 \%$ & $3 \%$ & $3 \%$ & $2 \%$ \\
\hline 6 & $W$. virilis & JQ034131 & 21 & 22 & 20 & 0 & 0 & - & $3 \%$ & $3 \%$ & $3 \%$ & $2 \%$ \\
\hline 7 & W. virilis & HQ848516 & 21 & 22 & 19 & 15 & 15 & 15 & - & $0 \%$ & $1 \%$ & $1 \%$ \\
\hline 8 & W. virilis & HQ848513 & 20 & 21 & 18 & 15 & 15 & 15 & 0 & - & $1 \%$ & $1 \%$ \\
\hline 9 & W. youdeoweii & HQ848496 & 22 & 23 & 19 & 13 & 13 & 13 & 3 & 3 & - & $0 \%$ \\
\hline 10 & W. youdeoweii & HQ848491 & 23 & 24 & 19 & 12 & 12 & 12 & 4 & 4 & 1 & - \\
\hline
\end{tabular}

\section{MATERIALS AND METHODS}

Twenty-six Synodontis zambezensis were collected by fyke nets during May and June 2018 in the Phongolo River in the Ndumo Game Reserve, north-eastern KwaZulu-Natal, South Africa (-26.925833; 32.325556). Following capture, fish were humanely killed by two adjunctive procedures: manually applied blunt force trauma to the cranium followed immediately by pithing of the brain (Permit no. OP 1582/2018; Ethics no. NWU-0015618-A5). The body cavity of euthanised specimens was opened by a mid-ventral incision and internal organs were removed and examined for endoparasites. The intestinal tract was opened and cestodes were transferred to a Petri dish with physiological saline. Live specimens were manually cleaned using a small brush.

A posterior part of a single specimen was cut with a scalpel and fixed in $96 \%$ ethanol for molecular studies. All other specimens were fixed in hot formaldehyde solution (4\%) for morphological studies. Fixed specimens were stained in Delafield's hematoxylin, dehydrated in a graded ethanol series, cleared in clove oil and placed in Canada balsam on microscopical slides. Morphological observations of specimens and line drawings were performed using a Nikon ECLIPSE Ni light microscope (Nikon Instruments, Tokyo, Japan) with a drawing attachment tube and Nomarski interference contrast. Measurements are in micrometres unless otherwise indicated, expressed as range with mean and standard deviation in parentheses. Cross sections could not be made because of the absence of adequate facilities and staff for making histological sections.

The terminology of individual body regions follows Woodland (1923) and Schaeffner et al. (2011, fig. 1), with several modifications adapted for present specimens as follows: The scolex of present specimens displays no clear posterior demarcation or well-defined base. The posterior delimitation of the scolex can only be ascertained by a slightly different, internal composition of cells in the adjacent testicular region as revealed under high magnification using a light microscope. The length of the testicular region therefore reaches from this ascertained posterior, internal boundary of the scolex to the centre of the genital atrium. The whole testicular field represents the space occupied by testes, which extend posteriorly beyond the genital atrium into the uterine region. The uterine region reaches from the genital atrium to the posteriormost border of the ovarian arms, while the uterine field represents the space occupied by the uterus from the anteriormost to posteriormost uterine arms. The postovarian region extends from the posteriormost border of the ovarian arms to the posteriormost extremity.
Selected specimens for scanning electron microscopy (SEM) were dehydrated in a graded ethanol series, placed in hexamethyldisilazane (HMDS) and allowed to air-dry. They were then placed on carbon tape on SEM stubs, coated with gold in an EIKO IB-2 ion coater (EIKO Engineering, Ltd., Yamazaki Hitachinaka, Japan) and observed with a Phenom Pro Desktop scanning electron microscope (Thermo Fisher Scientific Inc., Waltham, USA).

Type materials have been deposited in the National Museum, Bloemfontein, South Africa (NMB), Helminthological Collection of the Institute of Parasitology, Biology Centre of the Academy of Sciences of the Czech Republic, České Budějovice, Czech Republic (IPCAS) and the Natural History Museum, Geneva, Switzerland (MHNG-PLAT).

Total genomic DNA was extracted using $200 \mu \mathrm{l}$ of Chelex suspension $(5 \%)$ and $2 \mu \mathrm{l}$ of proteinase $\mathrm{K}$, followed by incubation for 6 hours at $56^{\circ} \mathrm{C}$, boiling at $90^{\circ} \mathrm{C}$ for $8 \mathrm{~min}$ and centrifugation at $15,000 \mathrm{rpm}$ for $10 \mathrm{~min}$. Polymerase chain reaction (PCR) was performed in $20 \mu \mathrm{l}$ reactions using $3 \mu \mathrm{l}$ of template DNA, $1.6 \mu \mathrm{l}$ of each of the primers, and $10 \mu$ of DreamTaq PCR Master Mix (Thermo Fisher Scientific Inc.). PCR primers used in this study were obtained from previously published studies and included LSU5 (5' TAGGTCGACCCGCTGAAYTTAAGCA 3') (Littlewood et al. 2000) and 1500R (5' GCTATCCTGAGGGAAACTTCG 3') (Tkach et al. 1999, 2003) for the partial 28S rDNA (D1-D3 region). Cycling conditions were as follows: initial denaturation for $5 \mathrm{~min}$ at $94^{\circ} \mathrm{C}$, followed by 40 cycles of $30 \mathrm{~s}$ at $94^{\circ} \mathrm{C}, 30 \mathrm{~s}$ at $55^{\circ} \mathrm{C}, 2 \mathrm{~min}$ at $72^{\circ} \mathrm{C}$ and completed by 7 min extension hold at $72{ }^{\circ} \mathrm{C}$. The product was verified on a $1 \%$ agarose gel using gel red and loading buffer and purified prior to sequencing using exonuclease I and shrimp alkaline phosphatase (Werle et al. 1994). Amplicons were Sanger sequenced at Inqaba Biotechnical Industries (Pty) Ltd. (Pretoria, South Africa) using the following internal primers: ZX-1 (5' ACCCGCTGAATTTAAGCATAT 3') (van der Auwera et al. 1994) and 1200R (5' GCATAGTTCACCATCTTTCGG 3') (Lockyer et al. 2003).

A contiguous sequence was assembled using Geneious version 7.1.3 (Kearse et al. 2012) for partial 28S rDNA (length of $553 \mathrm{bp}$ ). The reduced length of the sequence is most likely resulting from the postage of the molecular material and retention by customs services. A hologenophore (sensu Pleijel et al. 2008) was generated and deposited at NMB. The $28 \mathrm{~S}$ rDNA sequence was aligned with sequences of congeners obtained from GenBank (Table 1). Identical sequences of conspecific taxa were omitted, resulting in an alignment including 10 sequences of species of Wenyonia. The extremes were trimmed resulting in an alignment 
with 538 nucleotide positions. Genetic divergence was calculated for partial 28S rDNA sequences using the uncorrected p-distance model in MEGA7 software (Kumar et al. 2016). Due to the reduced length of the alignment, no molecular phylogenetic analysis was performed.

\section{RESULTS}

\section{Wenyonia gracilis sp. n.}

Figs. 1-4

ZooBank number:

urn:lsid:zoobank.org:act:D3BBF948-6D2E-4BF2-97E2-115022BD8193

Description (based on five mature specimens and two immature specimens used for SEM observations; measurements of eight complete and three fragmented immature specimens as Supplementary file 1). Body of mature specimens slender, elongate, nematoform (Fig. 1), 26.0-41.7 $\mathrm{mm}(32.9 \pm 5.2 \mathrm{~mm} ; \mathrm{n}=5)$ long, almost equal in width; maximum width in uterine region, 1,179-1,744 (1,424 \pm $184 ; \mathrm{n}=5$ ) (Fig. 1); constriction at level of cirrus-sac absent; width at level of cirrus-sac 931-1,419 (1,128 \pm 153 ; n $=6$ ). Ratio of body regions (scolex: testicular region: uterine region: postovarian region) 1.0: 17.7-22.1 (19.7 \pm 1.8 ; $\mathrm{n}=5): 20.3-29.1(24.2 \pm 3.1 ; \mathrm{n}=5): 11.0-22.1(16.1 \pm$ $3.5 ; \mathrm{n}=5$ ) (Fig. 2B). Length ratios of individual body regions: scolex $1.3-1.9(1.7 \pm 0.2 ; \mathrm{n}=5) \%$, testicular region 29.4-36.4 (32.3 $\pm 2.6 ; n=5) \%$, uterine region 37.6-41.1 $(39.4 \pm 1.3 ; \mathrm{n}=5) \%$, postovarian region $21.1-29.3(26.0 \pm$ $3.1 ; \mathrm{n}=5) \%$ of body length. Surface covered with acicular filitriches (Fig. 4D).

Scolex indistinct, 500-570 $(530 \pm 25 ; \mathrm{n}=6)$ long (Figs. 1, 3A, 4A-C). Testicular region long (Fig. 1), 9.5-12.3 mm $(10.5 \pm 1.0 \mathrm{~mm} ; \mathrm{n}=5)$ long by $835-1,384(1,123 \pm 184 ; \mathrm{n}$ =6) wide. Uterine region 10.1-16.1 mm (12.9 $\pm 1.9 \mathrm{~mm}$; $\mathrm{n}=5)$ long by $1,155-1,737(1,375 \pm 209 ; \mathrm{n}=5)$ wide (Fig. 1). Postovarian region variable in length, 5.5-12.2 $\mathrm{mm}(8.7$ $\pm 2.2 \mathrm{~mm} ; \mathrm{n}=5$ ) long (Fig. 1), slightly tapering posteriorly to blunt, almost rounded tip at posterior extremity (Figs. 1, 3B). Excretory canals cortical, very narrow and thinwalled in scolex (Fig. 3A), extending posteriorly to 3-4 narrow, lateral canals on each side, connected by centrally anastomosed canals (Fig. 3B,D,E). Excretory bladder thick-walled, elongate (Fig. 3B), near posterior extremity, connected to excretory gland; gland 31-106 (58 \pm 29 ; $\mathrm{n}=$ 6) long by $34-88(56 \pm 18 ; \mathrm{n}=6)$ wide (Fig. $3 \mathrm{~B})$; excretory pore terminal.

Scolex digitiform (Figs. 1, 3A, 4A-C), with shallow apical introvert (Figs. 3A, 4B, C); longitudinal furrows absent; scolex base not well-defined, without transverse band or constriction, 461-571 $(528 \pm 43 ; \mathrm{n}=6)$ wide. Testes medullary, subspherical, 449-548 $(494 \pm 41 ; n=3)$ in number (Fig. 1), in single layer, frequently overlapping, $75-99(91 \pm 7 ; \mathrm{n}=19)$ long by $58-86(71 \pm 9 ; \mathrm{n}=19)$ wide (Fig. 3D); anteriormost testes located 1.4-2.1 mm (1.8 \pm $0.3 \mathrm{~mm} ; \mathrm{n}=5$ ) posterior to scolex (Fig. 1), with few testes surrounding cirrus-sac; testes reach 842-1,006 (947 \pm $74 ; \mathrm{n}=3$ ) posterior to genital opening (Fig. 3D); testicular field 8.1-11.4 mm $(9.7 \pm 1.2 \mathrm{~mm} ; \mathrm{n}=4)$ long by 434-744 $(523 \pm 107 ; \mathrm{n}=6)$ wide (Fig. 1). Cirrus-sac oval, 669-853 $(753 \pm 65 ; \mathrm{n}=6)$ long by $420-546(492 \pm 39 ; \mathrm{n}=6)$ wide, occupying about half of body width (Fig. 3D). Male genital pore opens into common genital atrium (Fig. 3D). Genital atrium $47-116(84 \pm 21 ; n=6)$ long by $79-142(113 \pm 20 ; n$ $=6)$ wide, in posterior $21-34 \%(29 \pm 5 ; n=6)$ of cirrus-sac length (Fig. 3D).

Ovary follicular, bilobed, H-shaped in dorsoventral view (Fig. 3E), 1.3-3.0 mm (2.5 $\pm 0.6 \mathrm{~mm} ; \mathrm{n}=5)$ long by 672-969 (777 $\pm 122 ; n=5)$ wide; anterior ovarian arms longer and narrower than posterior arms, extending along $11-13(12 \pm 1 ; \mathrm{n}=6)$ posteriormost uterine coils (Fig. 1); anterior arms 160-301 (194 $\pm 40 ; \mathrm{n}=15)$ wide; posterior arms 202-387 (252 $\pm 52 ; \mathrm{n}=15)$ wide. Vagina tubular, slightly sinuous, 27-49 $(41 \pm 6 ; \mathrm{n}=18)$ wide (Fig. 3E). Seminal receptacle small, subspherical, 42-124 (89 \pm 32 ; $\mathrm{n}=5$ ) long by 56-104 (81 $\pm 19 ; \mathrm{n}=5)$ wide (Fig. 3E). Vitelline follicles small, 47-74 $(58 \pm 8 ; \mathrm{n}=19)$ long by $33-52(43 \pm 5 ; n=19)$ wide, increase in size posteriorly (Fig. 1); single longitudinal band of follicles present on each side of body in testicular and uterine regions (Fig. 1); follicular bands begin 1.6-2.2 mm (2.0 $\pm 0.2 \mathrm{~mm}$; $\mathrm{n}$ $=4$ ) posterior to scolex, occasionally reaching testicular field, narrower alongside cirrus-sac; few follicles occasionally interspersed in testicular field; fewer follicles present alongside ovarian arms (Fig. 3E). Postovarian vitelline follicles numerous, fill entire medulla, end 185-305 (220 \pm $44 ; \mathrm{n}=5$ ) from posterior extremity (Figs. 1, 4B).

Uterus tubular, forms numerous coils (Fig. 1); uterine field narrow and elongate, $8.8-14.6 \mathrm{~mm}(11.7 \pm 1.9 \mathrm{~mm} ; \mathrm{n}$ $=5)$ long by $757-1,215(970 \pm 155 ; \mathrm{n}=5)$ wide (Fig. 1$)$. Mehlis' gland 255-319 $(289 \pm 24 ; \mathrm{n}=4)$ long by $229-285$ $(257 \pm 20 ; n=4)$ wide (Fig. $3 E)$. Intrauterine eggs (measured in water) oval, operculate, $48-56(52 \pm 2 ; n=62)$ long by 27-34 (30 $\pm 1 ; \mathrm{n}=62)$ wide, containing fully-formed oncosphere with embryonic hooks (Fig. 3C); egg width/ length ratio $1.0: 1.5-2.0(1.7 \pm 0.1 ; \mathrm{n}=62)$.

Type and single host: Synodontis zambezensis Peters (Siluriformes: Mochokidae).

Type locality: Phongolo River, Ndumo Game Reserve, KwaZulu-Natal, South Africa (-26,925833; 32,325556).

Site of infection: Small intestine.

Prevalence: $35 \%$ (9 of 26 S. zambezensis examined).

In ten sity: $1-6$ specimens (mean intensity 2.3 worms per infected host).

Type material: Holotype deposited at NMB (P 590), paratypes in NMB (P 591-593), IPCAS (C-846) and MHNG (PLAT-137314-137319).

Etymology: The specific name gracilis refers to the body shape of specimens (gracilis in Latin = slender, thin).

Representative DNA sequence: partial sequence of the 28S rRNA gene 553 bp in length (GenBank accession number: MT945943). Hologenophore in NMB (accession number P 594).

\section{Differential diagnosis}

The species described herein is characterised by a nematoform, slender body with an almost equal width and a digitiform scolex. It thus differentiates from all congeners with the exception of $W$. acuminata. Wenyonia acuminata 

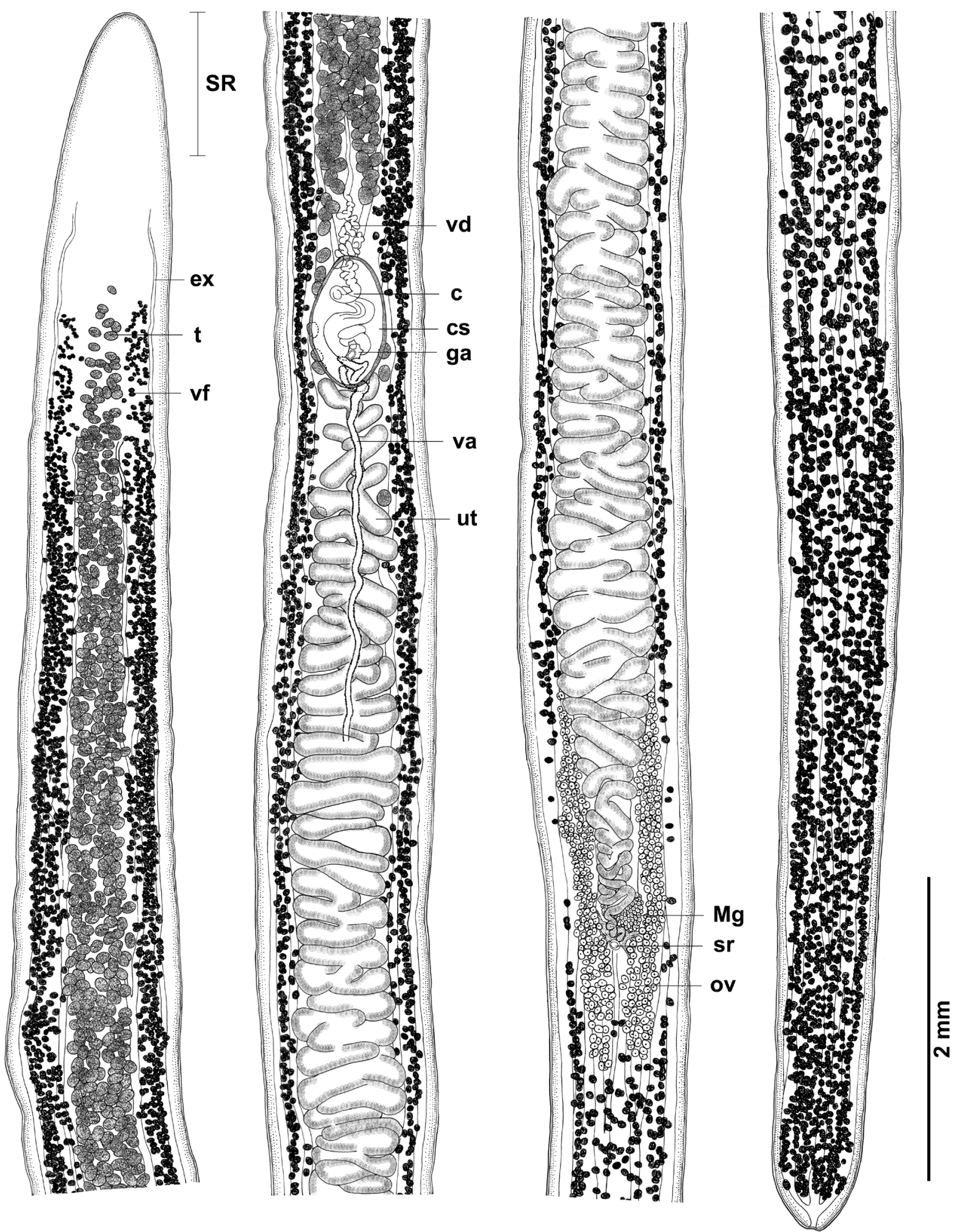

Fig. 1. Line drawing of a mature specimen of Wenyonia gracilis sp. n. from Synodontis zambezensis Peters, South Africa; holotype (NMB P 590). Abbreviations: c - cirrus; cs - cirrus-sac; ex - excretory canal; ga - genital atrium; Mg - Mehlis' gland; ov - ovary; sr seminal receptacle; SR - scolex region; $\mathrm{t}$ - testes; ut - uterus; va - vagina; vd - vas deferens; vf - vitelline follicles.

is distinguished from congeners by its body shape resembling that of a nematode, vitelline follicles arranged in two longitudinal rows and an almost equal length of testicular and uterine regions, which combined occupy about twothirds of the body length (Schaeffner et al. 2011).
Although $W$. acuminata and $W$. gracilis show striking morphological similarities in the general body shape, they differ in several external and internal features, which justify the recognition of $W$. gracilis as a separate species. One of the most prominent differences between the two species is the arrangement of postovarian vitelline follicles. 
A

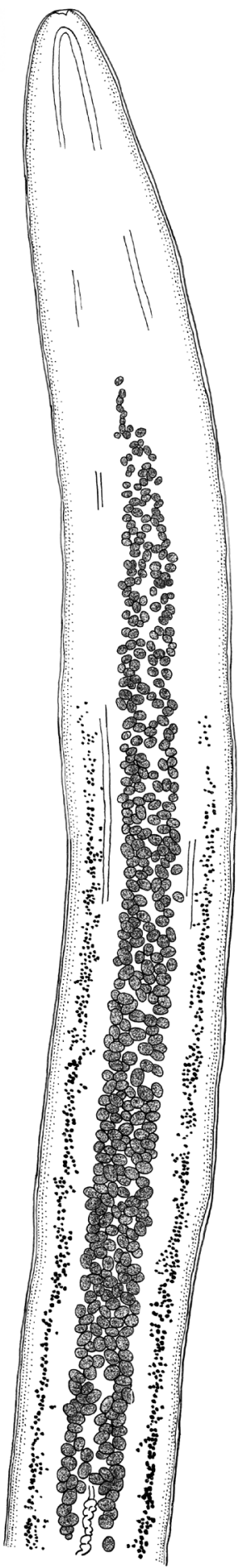

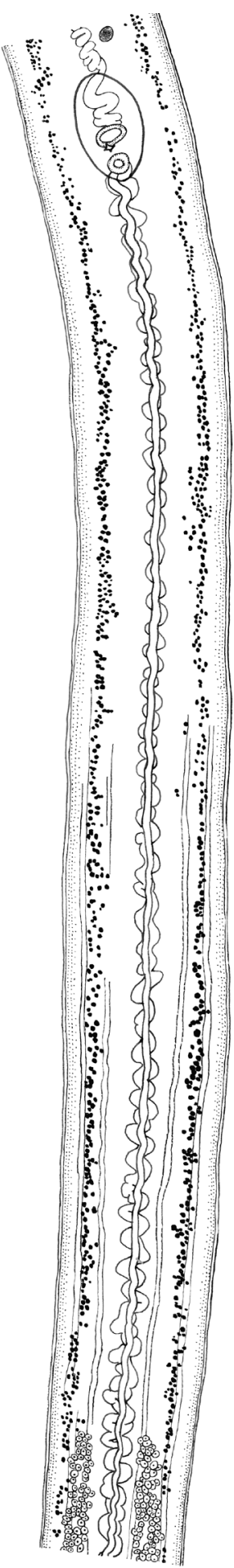
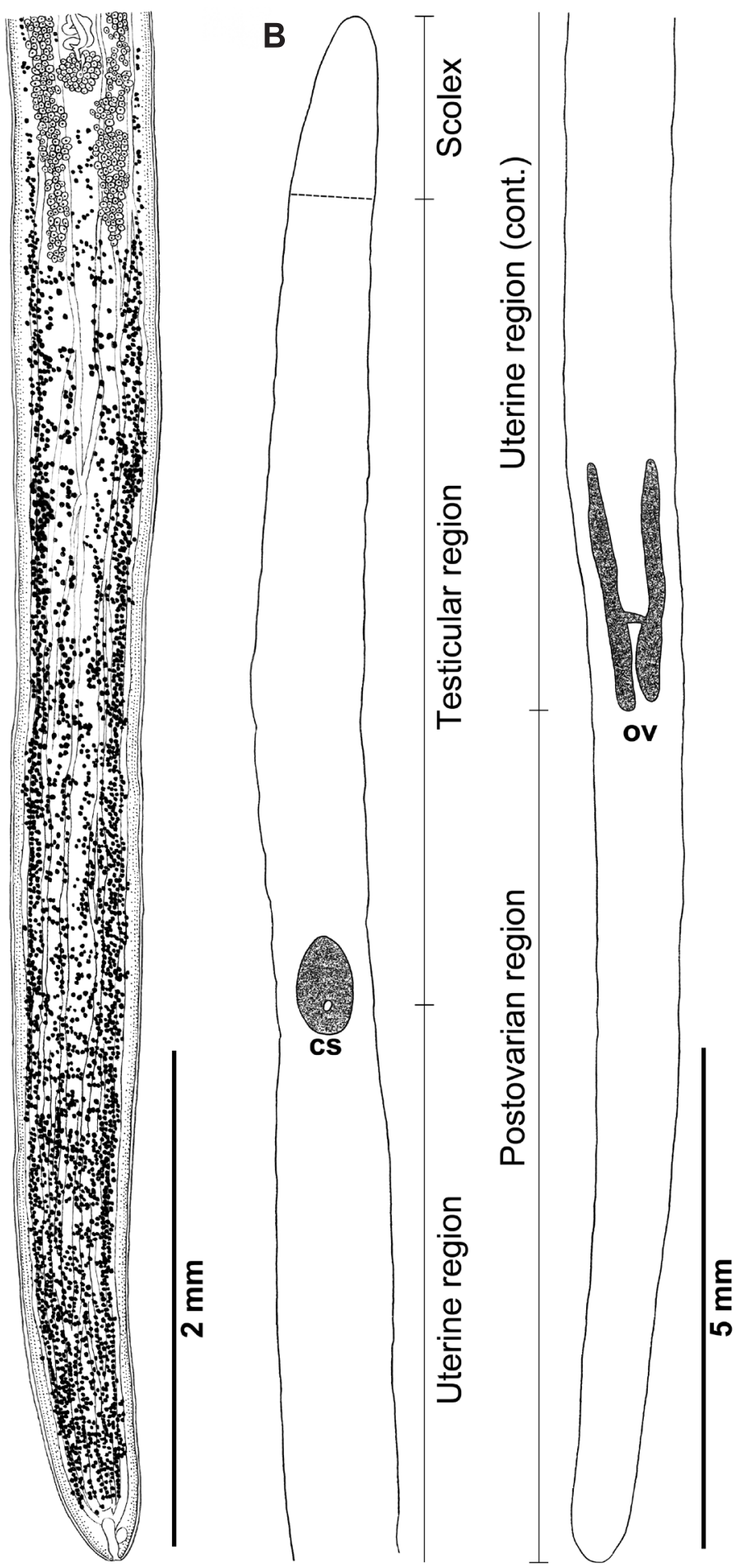

Fig. 2. Line drawings of Wenyonia gracilis sp. n. from Synodontis zambezensis Peters, South Africa. A - immature specimen; paratype (IPCAS C-146); B - outline of the body of a mature specimen; holotype (NMB P 590), showing individual body regions according to Woodland (1923). Scolex delimitation highlighted by dashed line. Abbreviations: cs - cirrus-sac; ov - ovary.

Wenyonia acuminata possesses two lateral bands of postovarian vitelline follicles, which are almost entirely absent medially. In contrast, the numerous postovarian vitelline follicles of $W$. gracilis fill the entire medulla and they are not arranged in longitudinal bands.

Furthemore, $W$. gracilis possesses a generally larger and wider body than $W$. acuminata, including the dimensions of internal body regions, such as the testicular, uterine and postovarian regions (Table 2). In contrast to W. acuminata, the body of $W$. gracilis appears wider in the uterine rather than the testicular region. The scolex of $W$. gracilis lacks longitudinal furrows and a well-defined base of chromophilic cells forming a transverse band as present in $W$. acuminata (see Schaeffner et al. 2011). Therefore, scolices of $W$. gracilis appear largely reduced and their delimitation can only be ascertained by a slightly different composition of cells in the adjacent testicular region. However, in contrast to scolices of $W$. acuminata, $W$. gracilis has a shallow apical introvert. 

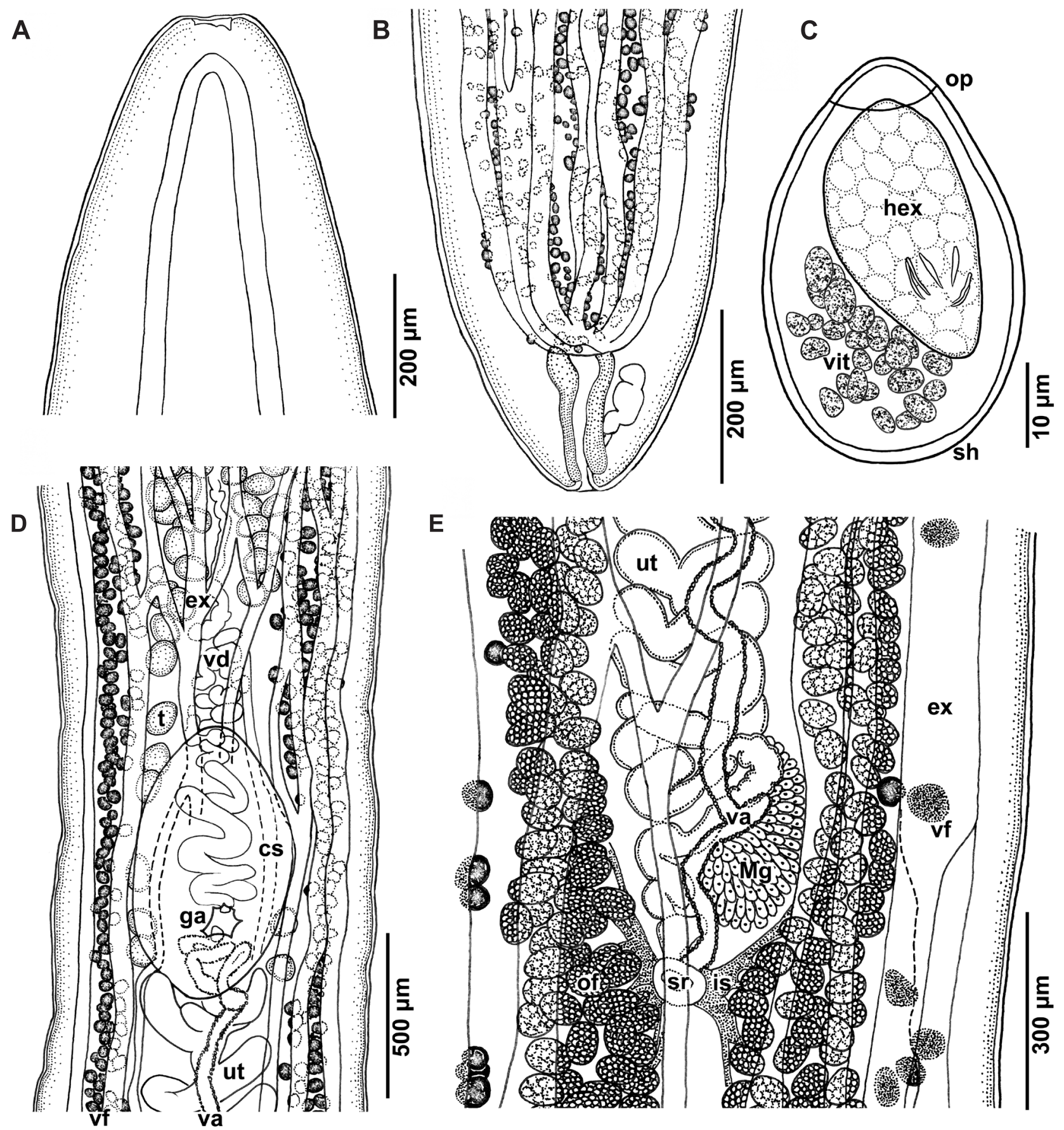

Fig. 3. Line drawings of Wenyonia gracilis sp. n. from Synodontis zambezensis Peters, South Africa. A - digitiform scolex with apical introvert; paratype (IPCAS C-146); B - caudal region with centrally anastomosed excretory canals, excretory bladder and gland; holotype (NMB P 590); C - embryonated egg with fully-formed hexacanth; D - region of the cirrus-sac, ventral view; holotype (NMB P 590); E - ovarian region, ventral view; holotype (NMB P 590); note: body margin not illustrated dextrally. Abbreviations: cs - cirrus-sac; ex - excretory canal; ga - genital atrium; hex - hexacanth; is - ovarian isthmus; Mg - Mehlis' gland; of - ovarian follicle; op - operculum; sh - shell; sr - seminal receptacle; $\mathrm{t}$ - testis; ut - uterus; va - vagina; vd - vas deferens; vf - vitelline follicle; vit - vitellocyte.

The testicular field of $W$. acuminata is restricted to the anterior margin of the cirrus-sac, whereas the testes of $W$. gracilis reach further posteriorly, with few scattered testes alongside the cirrus-sac and anteriormost uterine coils. The cirrus-sac of $W$. gracilis is thereby more pronounced and occupies almost half of the body width, whereas the one of $W$. acuminata is smaller and narrower, occupying roughly a third of the body width (Table 2). In addition, a constriction of the body in the region of the cirrus-sac as seen in
$W$. acuminata is absent. Moreover, eggs of $W$. gracilis are considerably larger than those of $W$. acuminata (Table 2).

The genetic divergence ( $\mathrm{p}$-distance) between $W$. gracilis and congeners included in the alignment ranged between four and five percent, representing more than 18 nucleotide differences in a $538 \mathrm{bp}$ fragment of the partial 28S rDNA region (Table 1). Surprisingly, $W$. acuminata presented the highest nucleotide divergence among all congeners with a p-distance of five percent (i.e. 23 to 24 nucleotide differ- 


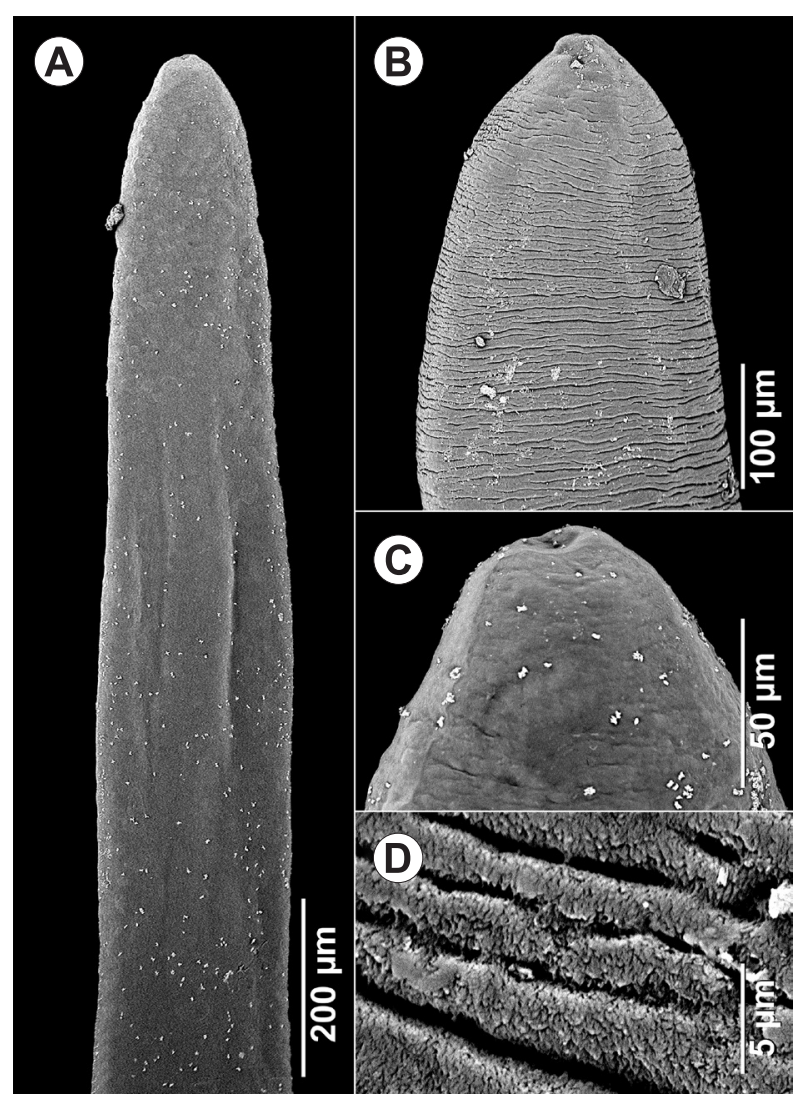

Fig. 4. Scanning electron micrographs of Wenyonia gracilis sp. n. from Synodontis zambezensis Peters, South Africa. A - anterior part of the body, including scolex, testicular and anterior uterine regions; $\mathbf{B}$ - scolex and anterior testicular region; $\mathbf{C}$ - detail of the anterior part of the scolex with shallow apical introvert; $\mathbf{D}$ acicular filitriches covering the entire body surface. ences). Although the alignment was reduced to a fraction of the length for the partial 28S rDNA region, the preliminary data presented herein confirms the morphological distinctiveness of $W$. gracilis as an independent and valid species of Wenyonia. With the exception of $W$. virilis, all other sequences of conspecific taxa included in the alignment did not present any genetic divergence in the p-distance values. Sequences of $W$. minuta were identical (i.e., 0 nucleotide differences), while sequences of samples of $W$. acuminata and $W$. youdeoweii differed by only a single nucleotide, respectively. The sequence of $W$. virilis (GenBank ID JQ034131) from the Sudan (Brabec et al. 2012) does not show any nucleotide differences to sequences of $W$. minuta but differs from sequences of conspecifics by 15 nucleotides. Although the current data cannot provide a clear conclusion, it appears that this sequence corresponds to a specimen of $W$. minuta rather than $W$. virilis.

A recent key for differentiating species of Wenyonia has been provided by Schaeffner et al. (2011) and, until now, no additional species has been described. Due to the similarity of $W$. gracilis and $W$. acuminata in body shape, a new key would separate both species from all other species of Wenyonia just as in the previous key from Schaeffner et al. (2011). For this reason, a new key including $W$. gracilis has not been provided.

\section{Remarks}

The description of $W$. gracilis increases the number of species within the genus to seven accepted taxa. The new species represents the first native caryophyllidean tapeworm described from southern African freshwater systems. It was recovered from $S$. zambezensis, an endemic species

Table 2. Comparative measurements of Wenyonia gracilis sp. n. and W. acuminata Woodland, 1923 from Synodontis catfishes (Mochokidae) in Africa. Measurements in micrometres unless otherwise stated; mean in parentheses (available only for the new species). Country abbreviations: CD - Democratic Republic of the Congo; SD - Sudan; ZA - South Africa.

\begin{tabular}{|c|c|c|c|}
\hline Species & Wenyonia gracilis sp. $\mathrm{n}$. & & inata \\
\hline Reference & Present study & Woodland (1923) & Schaeffner et al. (2011) \\
\hline Host & S. zambezensis & S. membranaceus & S. acanthomias \\
\hline Country & ZA & SD & $\mathrm{CD}$ \\
\hline Body length (mm) & $26.0-41.7(32.9)$ & $17.5-34.5$ & 23.7 \\
\hline Maximum width (mm) & $1.2-1.7(1.4)$ & $1.2-1.5$ & 0.9 \\
\hline Scolex ${ }^{1}$ length $(\mathrm{mm})$ & c. $0.5-0.6(0.5)$ & $2.5-4.0$ & $0.7-0.8$ \\
\hline Scolex ${ }^{1}$ width $(\mathrm{mm})$ & c. $0.5-0.6(0.5)$ & - & $0.5-0.6$ \\
\hline Testicular region ${ }^{1}$ length $(\mathrm{mm})$ & c. $9.5-12.3(10.5)$ & $7.5-11.0$ & 8.8 \\
\hline Uterine region ${ }^{1}$ length $(\mathrm{mm})$ & $10.1-16.1(12.9)$ & $5.0-13.5$ & $5.5-6.3$ \\
\hline Postovarian region ${ }^{1}$ length $(\mathrm{mm})$ & $5.5-12.2(8.7)$ & $2.5-6.5$ & 7.7 \\
\hline Uterine field ${ }^{1}$ length $(\mathrm{mm})$ & $8.8-14.6(11.7)$ & - & $5.5-5.6$ \\
\hline Uterine field ${ }^{1}$ width $(\mathrm{mm})$ & $0.8-1.2(1.0)$ & - & $0.4-0.5$ \\
\hline Testis number & $449-548(494)$ & - & $400-470$ \\
\hline Testis length & 75-99 (91) & - & 65-88 \\
\hline Testis width & $58-86(71)$ & - & $47-62$ \\
\hline Cirrus sac length & $669-853(753)$ & - & 420 \\
\hline Cirrus sac width & $420-546(492)$ & - & $280-300$ \\
\hline Ovary length $(\mathrm{mm})$ & $1.3-3.0(2.5)$ & - & $1.8-2.0$ \\
\hline Egg length & $48-56(52)$ & $35-37^{2}$ & $33-43$ \\
\hline Egg width & $27-34(30)$ & $22-26^{2}$ & $18-23$ \\
\hline
\end{tabular}




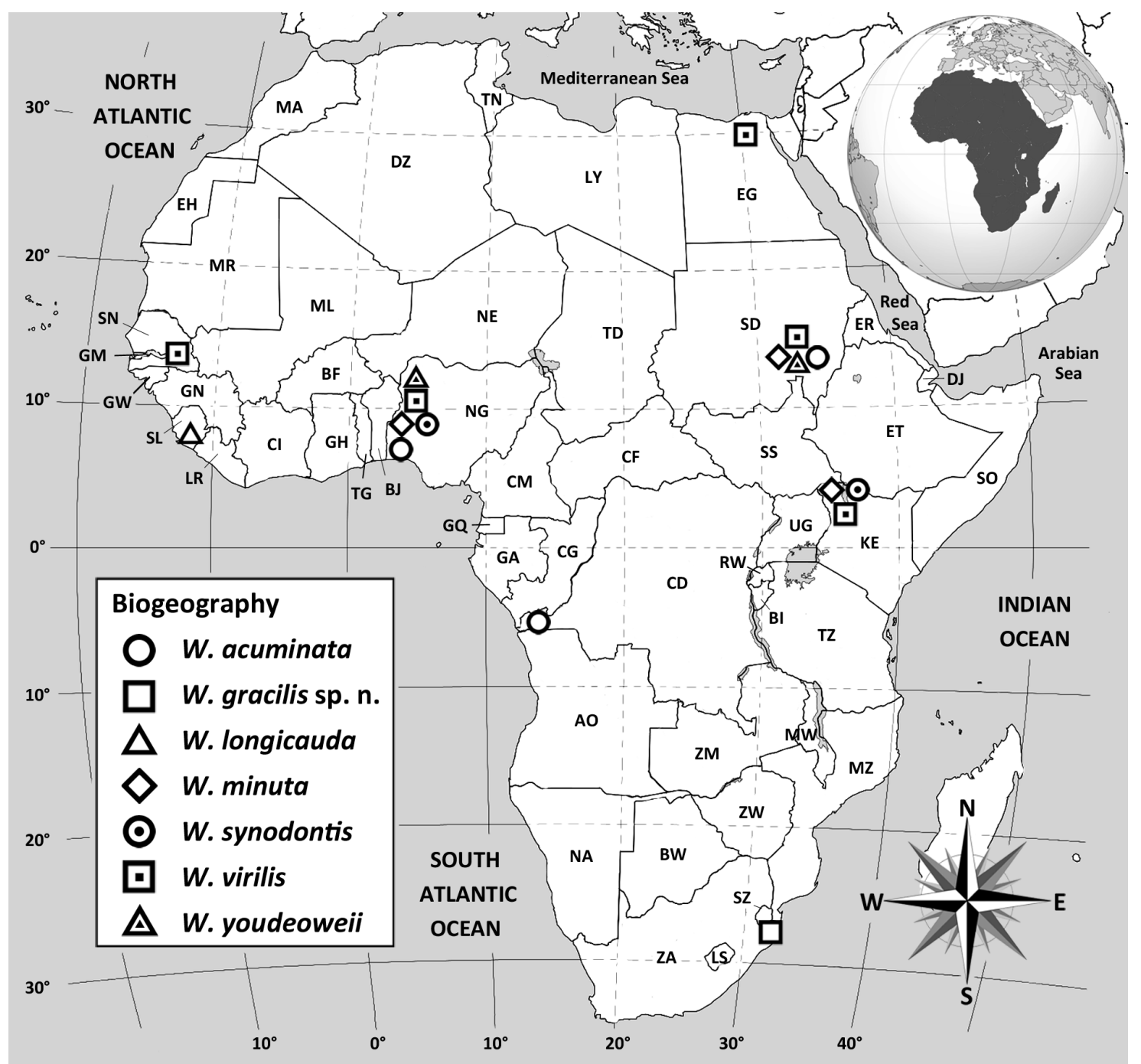

Fig. 5. Distribution of species of Wenyonia Woodland, 1923 (Cestoda: Caryophyllidea) from Synodontis catfishes in continental Africa. Abbreviations of international codes of continental African countries: AO - Angola; BF - Burkina Faso; BI - Burundi; BJ - Benin; BW - Botswana; CD - Democratic Republic of the Congo; CF - Central African Republic; CG - Republic of the Congo; CI - Ivory Coast; CM - Cameroon; DJ - Djibouti; DZ - Algeria; EG - Egypt; EH - Western Sahara; ER - Eritrea; ET - Ethiopia; GA - Gabon; GH - Ghana; GM - Gambia; GN - Guinea; GQ - Equatorial Guinea; GW - Guinea-Bissau; KE - Kenya; LR - Liberia; LS - Lesotho; LY - Libya; MA - Morocco; ML - Mali; MR - Mauritania; MW - Malawi; MZ - Mozambique; NA - Namibia; NE - Niger; NG - Nigeria; RW - Rwanda; SD - Sudan; SL - Sierra Leone; SN - Senegal; SO - Somalia; SS - South Sudan; SZ - Swaziland; TD - Chad; TG - Togo; TN - Tunisia; TZ - Tanzania; UG - Uganda; ZA - South Africa; ZM - Zambia; ZW - Zimbabwe.

of mochokid catfishes, with a narrow distributional range in the middle and lower Zambezi, the Limpopo and Phongolo systems (Froese and Pauly 2020). Carvalho Schaeffner (2018) listed a single protozoan species, two species of monogeneans, eight species of nematodes and two species of parasitic crustaceans as parasites of $S$. zambezensis. Therefore, $W$. gracilis is the first tapeworm reported from this fish host.

The restricted distribution of the host might limit the distributional range of its host-specific parasite, provided that $W$. gracilis has a strict (oioxenous) host specificity. However, other species of Synodontis occurring in this region, specifically in the Zambezi systems, such as $S$. leopardinus Pellegrin, S. macrostigma Boulenger, S. macrostoma Skelton et White, S. nebulosus Peters, S. nigromaculatus Boulenger, $S$. thamalakanensis Fowler, $S$. vanderwaali Skelton et White, and $S$. woosnami Boulenger (Bruwer and van der Bank 2003), have not been studied intensively for parasites (see Carvalho Schaeffner 2018).

Infected $S$. zambezensis showed a relatively low parasite intensity, with a maximum of six worms per host individual. Most infected host specimens $(n=7)$ carried parasite burdens of only one or two worms. Although the life cycles of species of Wenyonia are currently unknown, we assume that, similar to other caryophyllideans (Mackiewicz 1972), freshwater oligochaetes (Naididae) are utilised as intermediate hosts. In order to complete the life cycle, the infected oligochaetes need to be consumed by the definitive host. The definitive host, S. zambezensis, lives in pools and slow flowing perennial and seasonal rivers in southern Africa. With a complex mouth, this nocturnal benthic feeder utilises detritus and plant matter as well as small insects and snails as food sources (Skelton 2001). Therefore, the con- 
sumption of intermediate hosts, oligochaetes, may happen rather accidentally.

\section{DISCUSSION}

Caryophyllideans represent one of the principal cestode orders infecting evolutionarily old, benthic-feeding freshwater teleosts (orders Cypriniformes, Siluriformes and Osteoglossiformes) around the globe (Scholz and Kuchta 2017). Catfishes (Siluriformes) are dominant definitive hosts for caryophyllideans in the Ethiopian and Oriental zoogeographic regions, which form a monophyletic group (the newly circumscribed family Lytocestidae Hunter, 1927 - Scholz et al. 2021). In contrast, records of caryophyllideans in Neotropical siluriforms are entirely absent, despite the high diversity of siluriform hosts in this zoogeographic region (Scholz and Kuchta 2017). This is related to the fact that Neotropical siluriform fishes are phylogenetically distant from siluriform lineages that host caryophyllideans, such as bagriids, clariids, heteropneustids, mochokids and plotosids from other zoogeographic realms (Sullivan et al. 2006). Most caryophyllidean genera show a high degree of endemism (Mackiewicz 1982) and only a few genera have a disjunct distribution in more than one zoogeographic region, such as Caryophyllaeides Nybelin, 1922 (see Oros et al. 2017).

Several caryophyllideans such as Atractolytocestus huronensis, Khawia japonensis (Yamaguti, 1934), and K. sinensis Hsü, 1935 are invasive parasites that spread outside their original distributional areas by the introduction of their fish hosts, most notably the common carp, Cyprinus carpio, to different geographical areas (Scholz and Kuchta 2017). Prevalence of infection is generally low and may be affected by seasonal fluctuations, geographical distribution or host species infected (Mackiewicz 1972). However, if several host species are infected, these mostly belong to the same genus (see Schaeffner et al. 2011 for Wenyonia virilis).

Host specificity varies from oioxenous to euryxenous, with many caryophyllideans infecting a single host species to tapeworms that infect numerous host species of several genera (Scholz and Kuchta 2017, Scholz and Oros 2017). Most species of Wenyonia have a mesostenoxenous host specificity, infecting several species of a single host genus (Caira et al. 2003). Wenyonia virilis has been reported from 12 host species, whereas other congeners were found in six (Wenyonia minuta), four (Wenyonia synodontis and Wenyonia youdeoweii) and three (W. acuminata) species of Synodontis catfishes (Schaeffner et al. 2011). Wenyonia longicauda and Wenyonia gracilis are the only species of the genus with an oioxenous host specificity, infecting a single host species. However, only single records of these species exist (Woodland 1937; present study) and future parasitological observations might reveal additional definitive hosts or a wider geographical distribution.

The biogeographical distribution of species of Wenyonia has been limited to relatively few river systems in northern Africa (Egypt, Sudan) and northern (Nigeria, Senegal, Sierra Leone) to central regions of Sub-Saharan Africa (Democratic Republic of the Congo, Kenya). The description of $W$. gracilis from the Phongolo River now expands the geographical distribution of members of the genus south of the Zambezi River (Fig. 5). It furthermore represents the first finding of an autochthonous species of the order Caryophyllidea in southern Africa (Fig. 5).

Distributional ranges vary greatly between species of Wenyonia (Fig. 5). Wenyonia virilis is the most widely distributed species, occurring in the entire Nile River system (Egypt, Sudan), river basins in Western Africa (Nigeria, Senegal) and a permanent desert lake in eastern Africa (Lake Turkana) (Fig. 5). However, previous parasitological investigations into species of Wenyonia have been limited to only a few countries (see Smit et al. 2018), particularly the Sudan, Kenya and Nigeria. The latter constitutes the species richest country, with five recorded species of Wenyonia (Fig. 5).

This is mainly due to the efforts of the late Frank M.A. Ukoli (University of Ibadan, Nigeria), who described four species of Wenyonia, two of which have been recently synonymised with congeners (Schaeffner et al. 2011). The fifth Nigerian species, W. acuminata, was reported by Akinsanya et al. (2008), and represented the first finding of this species since its description by Woodland (1923) from the Sudan. Just recently, Schaeffner et al. (2011) further expanded the biogeographical distribution of $W$. acuminata after discovering specimens in $S$. acanthomias Boulenger in the Democratic Republic of the Congo. At the time, it marked the southernmost distribution of any species in the genus.

A total of four species of Wenyonia were recorded from the Sudan. Woodland (1923) described three of these species ( $W$. virilis, $W$. acuminata and $W$. minuta) from the Nile River at Khartoum, while Schaeffner et al. (2011) reported $W$. youdeoweii from three species of Synodontis from the White Nile (Kostí, Sudan). Recent investigations into the fish parasite fauna of Lake Turkana in Kenya revealed the presence of three species of Wenyonia, namely $W$. virilis, $W$. synodontis and $W$. minuta (see Schaeffner et al. 2011, Jirsová et al. 2017) (Fig. 5).

Two species of Wenyonia have been reported from only a single location in Africa: Wenyonia gracilis from South Africa and $W$. longicauda from Sierra Leone (Woodland 1937, present study) (Fig. 5). However, this is not surprising, given the sparse efforts of parasitological studies in most African countries. Since most species of Synodontis have not been screened for parasites (see Carvalho Schaeffner 2018), the number of species as well as their geographical distribution might be altered in the future, when new material becomes available.

Overall, data on African fish parasites are scarce and fragmented (Vanhove 2018), especially when compared to other continents, such as Europe or North America (Scholz et al. 2018). Given the high diversity and endemism of fishes in African freshwater systems, knowledge of fish parasites, their diversity, speciation and interactions becomes essential for future evolutionary and ecological studies. However, as illustrated for the siluriform genus Synodontis above, only a mere fraction of potential African fish hosts has been screened for parasites. 
General information on fish parasites is sparse and based on relatively low taxon coverage. The number of fish species examined for parasite infections therefore represents a rather small proportion of the rich freshwater fish fauna present in many African countries (Smit et al. 2018). Future research efforts should focus on countries or regions where information on fish parasites is limited or entirely lacking, and on fish species that have not been studied for parasites. This will provide us with crucial information on the actual biodiversity of fish parasites in Africa, knowledge of their life cycles, host associations and distribution, as well as the identification, distribution and monitoring of invasive species and causative agents of diseases in fisheries and aquaculture.

The description of a new species of caryophyllidean cestode from South Africa, where parasitological research has a long history especially in freshwater systems (Van As 2015), indicates the extent of the unknown and underexplored diversity of African fish parasites. These organisms have the potential to inform us about vital ecosystems processes, provide us with information on host populations and entire communities and even changes to ecosystem and population structures, and impacts of environmental fac- tors and climatic conditions on speciation and diversification events. Although parasitic organisms rarely appear in the spotlight of modern scientific research, the advantages of including parasite data in novel and combined scientific approaches are overwhelming. We just have to explore.

Acknowledgements. We are grateful to two anonymous reviewers for helpful suggestions and to members of the Water Research Group, North-West University (NWU) for their efforts during the sampling expedition at the Ndumo Game Reserve in 2018, in particular Anrich Kock, Coret Hoogendoorn, Marliese Truter, Rian Pienaar, and Victor Wepener. The authors are very grateful to Aline Angelina Acosta (NWU) for her help with DNA extractions. We also thank Anine Jordaan (NWU Laboratory for Electron Microscopy) and Willie Landman for taking micrographs and operating the scanning electron microscopes. Ezemvelo KZN Wildlife is acknowledged for providing the permit for host sampling in KwaZulu-Natal. This work was based on the research and researchers supported by the National Research Foundation (NRF) of South Africa (NRF Project CPRR160429163437; N.J. Smit, PI) and a NWU postdoctoral fellowship to BCS. Opinions, findings, conclusions and recommendations expressed in this publication are that of the authors, and the NRF accepts no liability whatsoever in this regard. This is contribution No. 491 from the NWU-Water Research Group.

\section{REFERENCES}

Akinsanya B., Hassan A.A., Adeogun A.O. 2008: Gastrointestinal helminth parasites of the fish Synodontis clarias (Siluriformes: Mochokidae) from Lekki Lagoon, Lagos, Nigeria. Rev. Biol. Trop. 56: 2021-2026.

Brabec J., Scholz T., Králová-Hromadová I., BazsalovICSOVÁ E., OLson P.D. 2012: Substitution saturation and nuclear paralogs of commonly employed phylogenetic markers in the Caryophyllidea, an unusual group of non-segmented tapeworms (Platyhelminthes). Int. J. Parasitol. 42: 259-267.

Bruwer E.E., van Der BAnK F. 2002: Biochemical genetic markers (hybrizymes) to identify Synodontis zambezensis $\times S$. nigromaculatus hybrids (Teleostei: Mochokidae). Biochem. Syst. Ecol. 30: 641-649.

Caira J. N., Jensen K., Holsinger K.E. 2003: On a new index of host specificity. In: C. Combes and J. Jourdane (Eds.), Taxonomy, Ecology and Evolution of Metazoan Parasites. Presses Universitaires de Perpignan, Perpignan, pp. 161-201.

Carvalho Schaeffner C.C. 2018: Chapter 5: Host-parasite list. In: T. Scholz, M.P.M. Vanhove, N. Smit, Z. Jayasundera and M. Gelnar (Eds.), A Guide to the Parasites of African Freshwater Fishes. ABC Taxa 18, Royal Belgian Institute of Natural Sciences, Brussels, pp. 361-402.

Froese R., Pauly D. 2020: FishBase. World Wide Web electronic publication. www.fishbase.org. Accessed 21 April 2020.

Jirsová D., ŠTEFKA J., JiRKU M. 2017: Discordant population histories of host and its parasite: a role for ecological permeability of extreme environment? PLoS ONE 12: e0175286.

Kearse M., Moir R., Wilson A., Stones-Havas S., Cheung M., Sturrock S., Buxton S., Cooper A., Markowitz S., Duran C., Thierer T., Ashton B., Meintues P., DrumMOND A. 2012: Geneious Basic: an integrated and extendable desktop software platform for the organization and analysis of sequence data. Bioinformatics 28: 1647-1649.

Khalil L.F., Polling L. (EDs.) 1997: Check List of the Helminth Parasites of African Freshwater Fishes. University of the North, Pietersburg, 185 pp.
Kumar S., Stecher G., Tamura K. 2016: MEGA7: Molecular Evolutionary Genetics Analysis 7.0 for bigger datasets. Mol. Biol. Evol. 33: 1870-1874.

Littlewood D.T.J., Curini-Galletti M., Herniou E.A. 2000: The interrelationships of Proseriata (Platyhelminthes: Seriata) tested with molecules and morphology. Mol. Phylogenet. Evol. 16: 449-466

Lockyer A.E., Olson P.D., Littlewood D.T.J. 2003: Utility of complete large and small subunit rRNA genes in resolving the phylogeny of the Neodermata (Platyhelminthes): implications and a review of the cercomer theory. Biol. J. Linn. Soc. 78: $155-171$.

MACKIEwiCz J.S. 1972: Caryophyllidea (Cestoidea): a review. Exp. Parasitol. 31: 417-512.

MaCKIEWICZ J.S. 1982: Caryophyllidea (Cestoidea): perspectives. Parasitology 84: 397-417.

Oros M., Choudhury A., Scholz T. 2017: A common Eurasian fish tapeworm, Caryophyllaeides fennica (Cestoda) in western North America: further evidence of 'amphi-pacific' vicariance in freshwater fish parasites. J. Parasitol. 103: 486-496.

Pleijel F., Jondelius U., Norlinder E., Nygren A., Oxelman B., Schander C., Sundberg P., Tholleson M. 2008: Phylogenies without roots? A plea for the use of vouchers in molecular phylogenetic studies. Mol. Phylogenet. Evol. 48: 369-371.

Schaeffner B.C., Jirk U M., Mahmoud Z.N., Scholz T. 2011: Revision of Wenyonia Woodland, 1923 (Cestoda: Caryophyllidea) from catfishes (Siluriformes) in Africa. Syst. Parasitol. 79: 83-107.

Scholz T., Kuchta, R. 2017: A digest of fish tapeworms. Vie et Millieu 67: 43-58.

Scholz T., Kuchta, R. 2018: Chapter 4.6. Cestoda. In: T. Scholz, M.P.M. Vanhove, N. Smit, Z. Jayasundera and M. Gelnar (Eds.), A Guide to the Parasites of African Freshwater Fishes. ABC Taxa 18, Royal Belgian Institute of Natural Sciences, Brussels, pp. 269-286.

Scholz T., Oros M. 2017: Caryophyllidea van Beneden in Carus, 1863. In: J.N. Caira and K. Jensen (Eds.), Planetary Biodiversity Inventory (2008-2017): Tapeworms from Vertebrate Bowels of 
the Earth. University of Kansas, Natural History Museum, Special Publication No. 25, pp. 47-64.

Scholz T., Tavakol S.., Halajian A., Luus-Powell W.J. 2015: The invasive fish tapeworm Atractolytocestus huronensis (Cestoda), a parasite of carp, colonises Africa. Parasitol. Res. 114: 3521-3524.

Scholz T., Vanhove M.P.M., Smit N., Jayasundera Z., GelNAR M. (EDS.) 2018: A Guide to the Parasites of African Freshwater Fishes. ABC Taxa 18, Royal Belgian Institute of Natural Sciences, Brussels, 424 pp.

Scholz T., Waeschenbach A., Oros A., Brabec J., Littlewood D.T.J. 2021: Phylogenetic reconstruction of early diverging tapeworms (Cestoda: Caryophyllidea) reveals ancient radiations in vertebrate hosts and biogeographic regions. Int. $J$. Parasitol. (in press).

Skelton P. 2001: A Complete Guide to the Freshwater Fishes of Southern Africa. Struik Publishers, Cape Town, 395 pp.

Smit N.J., Basson L., Vanhove M.P.M., Scholz T. 2018: History of fish parasitology in Africa. In: T. Scholz, M.P.M. Vanhove, N. Smit, Z. Jayasundera and M. Gelnar (Eds.), A Guide to the Parasites of African Freshwater Fishes. ABC Taxa 18, Royal Belgian Institute of Natural Sciences, Brussels, pp. 16-29.

Sullivan J.P., Lundberg J.G., Hardman M. 2006: A phylogenetic analysis of the major groups of catfishes (Teleostei: Siluriformes) using rag1 and rag2 nuclear gene sequences. Mol. Phylogenet. Evol. 41: 636-662.

Tkach V.V., Grabda-Kazubska B., Pawlowski J., SwiderSKI Z. 1999: Molecular and morphological evidence for close phylogenetic affinities of the genera Macrodera, Leptophallus, Metaleptophallus and Paralepoderma (Digenea, Plagiorchiata). Acta Parasitol. 44: 170-179.
TKach V.V., Littlewood D.T.J., Olson P.D., Kinsella J.M., Swiderski Z. 2003: Molecular phylogenetic analysis of the Microphalloidea Ward, 1901 (Trematoda: Digenea). Syst. Parasitol. 56: $1-15$.

UкоLI F.M.A. 1972: Occurrence, morphology and systematics of caryophyllaeid cestodes of the genus Wenyonia Woodland, 1923 from fishes in River Niger, Nigeria. J. West Afr. Sci. Assoc. 17: $49-67$.

VAN As J.G. 2015: A brief history of freshwater fish parasitology in southern Africa. Afr. Zool. 50: 93-107.

Van der Auwera G., Chapelle S., de Wachter R. 1994: Structure of the large ribosomal subunit RNA of Phytophthora megasperma, and phylogeny of the oomycetes. FEBS Lett. 338: 133-136.

VANHOVE M.P.M. 2018: Evolutionary parasitology of African freshwater fishes and its implications for the sustainable management of aquatic resources. In: T. Scholz, M.P.M. Vanhove, N. Smit, Z. Jayasundera and M. Gelnar (Eds.), A Guide to the Parasites of African Freshwater Fishes. ABC Taxa 18, Royal Belgian Institute of Natural Sciences, Brussels, pp. 403-412.

Werle E., Schneider C., Renner M., Völker M., Fiehn W. 1994: Convenient single-step, one tube purification of PCR products for direct sequencing. Nucl. Acids Res. 22: 4354-4355.

WoOdLAND W.N.F. 1923: On some remarkable new forms of Caryophyllaeidae from the Anglo-Egyptian Sudan, and a revision of the families of the Cestodaria. Q. J. Microsc. Sci. 67: 435-472.

Woodland W.N.F. 1937: Some cestodes from Sierra Leone. I. On Wenyonia longicauda, sp. n., and Proteocephalus bivitellatus, sp. n. Proc. Zool. Soc. Lond. 4: 931-937.

Cite this article as: Schaeffner B.C., van Rooyen D., Gerber R., Scholz T., Smit N.J. 2020: Wenyonia gracilis sp. n. (Cestoda: Caryophyllidea) from Synodontis zambezensis (Siluriformes: Mochokidae): the first native caryophyllidean tapeworm from southern Africa. Folia Parasitol. 67: 035. 